

\title{
Ta'dibuna
}

Jurnal Pendidikan Islam

Vol. 3, No. 1, 2014, p-ISSN: 2252-5793

\section{Metode Pengajaran Sejarah Menurut Hamka}

\author{
Mas'ud HMN1, Adian Husaini' ${ }^{2}$, Didin Saefuddin ${ }^{3}$ \\ ${ }^{1}$ Universitas Muhammadiyah Prof Dr Hamka Jakarta, Indonesia \\ ${ }^{2}$ (Coresponding author) Universitas Ibn Khaldun Bogor, Indonesia \\ ahusaini@uika-bogor.ac.id dan ahusaini @yahoo.com \\ 3 Universitas Islam Negeri Syarif Hidayatullah Jakarta, Indonesia
}

\begin{abstract}
This study aims at examining the Hamka's concept of history education through a descriptive analysis of his life history and his historical works. Through reviewing Hamka life history, it is hope to know how did he make himself to became a historian. While by analyzing Hamka historical works, it is hope to know how did he use the methods of historical thinking in his works. Based on these the Hamka's concept of history education is then reconstructed whit the emphasis on the goal and method of historical teaching. From the analysis of Hamka life history by framing how he established himself in the field of history, it is concluded that Hamka (1) has a high "interest" in the historical field that grow naturally being raised in an environment that is rich with the art of storytelling (bakaba) and (2) has a high "self efficacy" in independent learning that grow instead of failure in the formal school and then reinforced with a mastery of Islamic Jurisprudence and logic that deliberately was taught by his father in order not to mislead in learning all areas of his interest independently. Especially in the field of history Hamka learn by (3) "observing", i.e. looking, listening, and asking about the origins of events and important figures in his surrounding environment and in other countries he journeyed, (4) "reading", i.e. own attempting to gain an understanding of the various readings of history, whether written by the classical historian of Islam, the traditional local historians, and the modern historians including the orientalist and foreign writers, and (5 "writing", which reproduces the understanding gained from the observations and readings by using his own angle of view, interpretation, and style. Further analysis using the framework of Seixas "historical thinking" on Hamka's Ayahku: Riwayat Hidup Dr. H. Abdul Karim Amrullah dan Perjuangan Kaum Agama di Sumatra Barat ("My Father: The History of Dr. H. Abdul Karim Amrullah and The Religious Struggle in West Sumatra"), it is clearly visible Hamka's ability to use historical thinking. In this work Hamka successfully "demonstrate the significance of history", "use of historical sources", "analyze continuity and change in history", "take a historical perspective", and "presents a moral message of history". As a self-taught in history, Hamka's ability intuitively derived from an intelligent reading of the historical works and present his own understanding of learning by way of writing it (writing to learn). What is achieved by this self-taught Hamka, should be achieved by anyone who studied history in formal education. Based on the life history of how Hamka establish himself as a student of history and an analysis of his original work Ayahku, it can be formulated concept Hamka's history education that useful in developing an ideal history education. From Hamka's life history, the keywords in his history education is "interest", "self-efficacy", "observing", "reading" and "writing". While from his historical work analysis the keyword is "think historical-
\end{abstract}


ly." If all the keywords are formulated through a concise definition, then Hamka's concept of history education is "fostering interest and self-efficacy of students in historical thinking through the activities of observing, reading, and writing about history."

Keywords: Hamka, teaching method, history

\section{Pendahuluan}

Para ahli sepakat bahwa salah satu cara al-Quran menjelaskan pesannya adalah melalui kisah-kisah. Namun kisah-kisah yang disampaikan bukan dongeng, melainkan kejadian-kejadian nyata di masa lalu yang harus dijadikan pelajaran (i'tibar) bagi umat manusia. [1] Manusia harus memetik pelajaran dari peristiwa masa lalu itu agar mereka dapat menentukan pilihan tindakan yang tepat di masa sekarang sehingga kelak tidak terjerumus ke dalam lobang yang sama. $\left[{ }^{2}\right]$ Semangat Al-Quran inilah rupanya yang mendorong para ulama untuk menaruh kepedulian pada sejarah, sehingga ada di antara mereka yang selain ahli menafsirkan kitab suci juga dikenal ahli menafsirkan sejarah, seperti At-Tabari, [3] Ibnu Katsir, [4] hingga Hamka. [5]

Hamka adalah ulama pujangga yang melahirkan banyak karya dalam berbagai bidang yang tersebar luas di dunia berbahasa Melayu Asian Tenggara. Di antara lebih seratus karyanya, Tenggelamnya Kapal van der Wijk (1937), Tasawuf Moderen (1939), Lembaga Hidup (1962), dan Tafsir Al-Azhar (1966) merupakan karya puncak di bidang sastra, tasawuf, akhlak, dan tafsir yang masih dicetak ulang di Jakarta, Malaysia, dan Singapura. Di bidang sejarah, Hamka juga menulis beberapa karya monumental, antara lain Ayahku (1950), Kenang-kenangan Hidup (1951, tiga jilid), Sejarah Muhammadiyah di Minangkabau (1974), dan Sejarah Umat Islam (1949-1961, empat jilid). Dipandang dari ilmu historiografi, keempat buku tersebut dapat dikategorikan sebagai sejarah agama dengan genre-secara berturut-turut-biografi, otobiografi, sejarah lokal, dan sejarah total. Namun selain itu Hamka juga menulis buku-buku genre sejarah pemikiran atau sejarah mentalitas seperti Pengaruh Muhammad Abduh di Indonesia (1958), Tasawuf: Perkembangan dan Pemurniannya (1952), Perkembangan Kebatinan di Indonesia (1990). Kepiawaian Hamka dalam berurusan dengan sumber sejarah dan penafsiran sejarah, terlihat dalam karya polemisnya, Antara Fakta dan Khayal Tuanku Rao (1974) yang merupakan sanggahan terhadap karya Parlindungan, Tuanku Rao (1965).

Walaupun Hamka telah menulis karya dalam genre sejarah yang amat beragam itu, hingga saat ini kapasitsanya sebagai sejarawan belum memperoleh tempat yang layak dalam historiografi Islam modern di Indonesia. Ayumardi Azra dalam bukunya Historiografi Islam Kontempor,[6] misalnya, tidak sekalipun menyinggung karya-karya sejarah Hamka dalam bagian pembahasannya tentang "Wacana dan Konsep Sejarah" (Bagian Pertama) atau "Aktualitas Sejarah" (Bagian Kedua). Memang di buku itu ada memuat tulisan khusus tentang Hamka,[7] namun Hamka disajikan hanya dalam kapasitasnya sebagai tokoh sejarah dalam "Para Pelaku Sejarah Moderen" (Bagian Ketiga) tanpa sedikitpun menyinggung kepeduliannya terhadap sejarah. Sebagai pelaku 
sejarahpun karya-karya Hamka nyaris diabaikan dalam penulisan sejarah di Indonesia. Misalnya dalam buku Sejarah Umat Islam Indonesia[8] tidak satupun karya Hamka sejarah dijadikan rujukan, padahal buku itu ditulis beberapa sejarawan akademisi Muslim sebagai proyek dari Majlis Ulama Indonesia.

Kurangnya penghargaan kepada Hamka sebagai sejarawan tampaknya terkait dengan perkembangan pesat sejarah sebagai ilmu di satu sisi dan di sisi lain dengan makin dominannya sejarawan akademis dalam dinamika keilmuan sejarah Indonesia moderen. Sejarah sebagai ilmu, menurut Kuntowijoyo, telah berkembang sebagai ilmu mandiri yang menutut keahlian yang sangat spesifik dalam berurusan dengan sumber, metode, teori, pendekatan, dan penjelasan sejarah yang berbeda coraknya dengan ilmu sosial yang lain.[$\left.{ }^{9}\right]$ Ilmu sejarah telah menjadi disiplin tersendiri yang dilembagakan dalam program studi jenjang sarjana hingga pascasarjana, sehingga seorang "sejarawan" diragukan kepakarannya jika tidak dididik secara formal dalam bidang ilmu tersebut. Maka Hamka yang bukan "sarjana sejarah"—-bersama Yousuf Souyb, Zainal Abidin Ahmad, dan A. Hasymi-yang selama ini mendominasi penulisan sejarah Islam di Indonesia, menurut Didin Saefuddin Buhcori "secara jujur tidak dapat digolongkan sebagai sejarawan sehingga banyak para sarjana sejarah kurang mengapresiasinya" (kursif ditambahkan).[10] Dalam penilaian Buchori, dengan menggunakan kategori yang dibuat oleh Kuntowijoyo, keempat penulis sejarah Islam itu tidak bisa digolongkan ke dalam "sejarawan profesional" maupun "sejarawan dari disipilin ilmu lain," melainkan paling banter hanya sebagai "sejarawan dari masyarakat" yaitu "sejarawan amatir yang tidak bertitel sarjana kendatipun belum tentu buruk dalam menulis sejarah." [11]

Pengkategorian berdasarkan latar belakang pendidikan ini tampaknya telah menjadi standar untuk diterimanya seorang penulis sejarah ke dalam golongan "sejarawan." Demikianlah, sewaktu Kongres Nasional Sejarah VII dan Kongres Masyarakat Sejarawan Indonesia V, sempat terjadi pro dan kontra untuk mengangkat Rosihan Anwar dan Ramadhan KH sebagai Anggota Kehormatan, karena keduanya dianggap bukan sejarawan akademik (academic historian) melainkan "sejarawan informal" (informal historian).[12] Baik Rosihan Anwar, Ramadhan KH, maupun Hamka memang bukan sejarawan akademik jika latar belakang pendidikan dijadikan tolok ukur. Bahkan ketiganya bukan jebolan perguruan tinggi, sehingga lengkaplah sudah untuk menempatkan mereka sebagai "sejarawan informal." Akan tetapi sebagai wartawan dan penulis yang menyaksikan sejarah dari pandangan pertama, karya-karya "petite history" Rosihan Anwar[13] atau karya-karya biografis Ramadhan KH, [14] harus diakui sumbangannya bagi penulisan sejarah Indonesia modern. Untuk Hamka sendiri yang merupakan saksi sekaligus pelaku sejarah Islam modern di Indonesia, karya-karya semestinya juga dianggap sebagai sumber yang amat berharga bagi sejarah Indonesia modern, suatu pendirian yang dianut oleh sejarawn LIPI Taufik Abdullah.[15]

Terkait dengan penelitian ini, kiranya menggali konsep pendidikan sejarah Hamka dengan menggunakan pendekatan berpikir historis ini relevan untuk dilakukan. Menurut Taufik Abdullah, yang menulis tentang Hamka dalam Oxford Encyclopedia of The Modern Islamic World: “Sebagai pengkaji sejarah yang kritis, Hamka tidak saja menjadikan masa lalu hidup kembali melainkan juga berhasil menemukan pesan-pesan 
moral yang dikandung sejarah untuk masa kini."[16] Menemukan pesan-pesan moral dari sejarah inilah yang menjadi tujuan akhir dari pendekatan berpikir historis dalam pendidikan sejarah. Dan sebagaimana pendapat Tarif Khalidi, sejarawan dari American University of Beyrut, pelajaran moral yang disebut Al-Quran sebagai 'ibrah inilah sesungguhnya yang menjadi tujuan Tuhan memaparkan berbagai kisah dalam Al-Quran. Capaian yang diraih Hamka di bidang sejarah yang ditempuhnya secara otodidak ini patut dijadikan ilham dengan menelusuri bagaimana dia membentuk dirinya sendiri sebagai sejarawan dan bagaimana proses berpikir historis itu terpantul dalam karyakarya sejarahnya sehingga dapat dirumuskan "konsep pendidikan sejarah menurut Hamka."

\section{Metodologi}

Obyek penelitian ini adalah konsep pendidikan sejarah menurut Hamka. Konsep pendidikan sejarah Hamka itu digali dari cara Hamka belajar sejarah dan dari cara Hamka menggunakan metode berpikir historis dalam karya sejarahnya. Dengan demikian akan dapat dirumuskan metode pengajaran sejarah menurut Hamka.

Sebagai kajian konseptual, maka sumber data bagi penelitian ini adalah dokumen tertulis yang dapat dibedakan ke dalam dua kategori. Yang pertama adalah sumber primer berupa karya Hamka sendiri, yang mencakup riwayat hidup dan karya sejarah yang ditulis oleh Hamka. Untuk riwayat hidup, sumber primernya adalah KenangKenangan Hidup 4 Jilid (1950) sedangkan untuk cara berpikir historis sumber primernya adalah Ayahku (). Karya-karya Hamka yang lain, terutama Tafsir Al-Azhar (), Sejarah Umat Islam () serta Tuanku Rao () juga termasuk ke dalam sumber primer yang melengkapi kedua sumber primer tersebut. Termasuk ke dalam sumber primer adalah konsep berpikir historis, terutama sebagaimana dikembangkan oleh Seixas, digunakan untuk menganalisis karya sejarah Hamka. Untuk sumber sekunder, terutama menyangkut riwayat hidup, digunakan berbagai karya yang membahas tentang Hamka, misalnya karya Rusydi Hamka, Azyumardi Azra, dan sebagainya.

Data dikumpulkan dengan menghimpun dokumen-dokumen terkait berupa sumber primer dan sumber sekunder itu sendiri. Baik sumber primer dan sumber sekunder dikumpulkan melalui penelusuran bahan kepustakaan tercetak dan bahan kepustakaan elektronik. Untuk berpikir historis, bahan kepustakaan elektronik seperti e'book dan artikel e'journal, lebih banyak digunakan. Dokumen elektronik ini dihimpun dengan bantuan mesin pencari Goegle dengan menggunakan kata kunci "historical thinking," "Seixas," dan seterusnya.

Kajian ini menggunakan metode penelitian kepustakaan dengan teknik analisis deskriptif. Dengan metode kepustakaan maksudnya kajian menggunakan sumbersumber tertulis, entah yang ditulis langsung oleh Hamka atau pakar lain tentang Hamka, sebagai bahan utamanya. Dengan pendekatan teknik analisis deskriptif maksudnya bahan-bahan kepustakanaan itu dibahas untuk membuat gambaran yang terinci tentang berbagai aspek yang ingin dijawab dalam pertanyaan penelitian. Dalam menjawab masalah penelitian pertama, riwayat hidup Hamka dianalisis secara menyeluruh namun dengan framing bagaimana minat dan kemampuannya tumbuh dan berkembang 
tentang sejarah dari masa kecil hingga masa tua. Dalam menjawab masalah penelitian kedua, dianalisis salah satu karya utamanya yang paling orisinil dengan menggunakan kerangka berpikir historis. Selanjutnya berdasarkan temuan dari kedua analisis tersebut, dilakukan rekonstruksi konsep pendidikan sejarah Hamka.

\section{Hasil Dan Pembahasan}

Pada bagian awal telah dijelaskan bahwa Hamka tidak pernah menulis secara khusus tentrang konsep pendidikan sejarah. Namun demikian, mengingat keterlibatan dan kepeduliannya terhadap sejarah sebagai tercermin dalam sejarah hidupnya dapat ditarik suatu benang merah yang menggambarkan konsep pendidikan sejarah Hamka, suatu konsep yang tidak diwacanakan atau diajarkan Hamka melainkan diterapkannya dalam mendidik dirinya sendiri selaku seseorang yang belajar otodidak sepanjang hayat.

\section{A. Sejarah sebagai Ilmu}

Istilah "sejarah" merupakan penggunaan Indonesia untuk "tarikh" (Arab) atau "history"). Secara Bahasa kata "syajarah" yang berarti "pohon" berasal kebiasaan bangsa Arab membuat silsilah keturunannya dalam bentuk suatu pohon. Hamka menjelaskan asal usul penggunaan istilah itu sebagi berikut:

Bangsa Arab adalah bangsa yang cermat sekali menjaga nasab (turunan)nya. Kadang-kadang mereka hapal "bin" dan "bin" dan "bin" itu di luar kepala sampai 30 turunan. Kadang-kadang mereka tuliskan menyerupai sebuah syajarah (pohon kayu) sejak pangkal uratnya, sampai dahan-dahannya, sampai ranting-rantingnya, sehingga kata syajarah yang berasal dari ranjian nasab (turunan) itu telah kita ambil, untuk memperkaya Bahasa kita, lalu kita sebut sejarah, yang berarti tarikh.[17]

Hamka tidak menjelaskan lebih lanjut mengenai makna sejarah atau tarikh secara istilah. Memang dalam bukunya yang memuat kutipan di atas Hamka tidak bermaksud menjelaskan konsep sejarah, karena buku tersebut dimaksudkan sebagai respon terhadap karya Parlindungan, Tuanku Rao. Dalam karya ini Hamka menyorot apa yang diklaim oleh Parlindungan sebagai fakta sejarah di seputar Kaum Padri yang menurut Hamka hanyalah khayal belaka. Walaupun lebih banyak menyorot tentang fakta-fakta sejarah, namun di sana sini Hamka menyelipkan juga pandangannya tentang hakikat sejarah dan metodologinya. Misalnya, mengenai hakikat sejarah Hamka menjelaskan sebagai berikut:

Bagi saya sejarah itu hanyalah fakta dan data, bukti dan catatan yang kita terima dari pada orang yang dahulu dari pada kita. Dan kita tidak melihat sendiri lagi kejadian itu karena ruang dan waktunya sudah lampau. Oleh sebab itu untuk menilai, mempertautkan di sana sini, perlulah kita pakai fikiran kita: yaitu fikiran yang teratur. Fikiran yang teratur itulah yang mempunyai peralatan berfikir; premis I, premis II dan kesimpulan. (kursif ditambahkan).

Dari kutipan di atas tampaklah peran penting logika dalam pemahaman sejarah Hamka. Pentingnya logika dalam pemahaman sejarah ini sesungguhnya bukan 
prendapat baru. Sebagaimana dikemukakan oleh sejarawan Itali Benedeto Croce, "History, being the individual judgment, is the synthesis of subject and predicate, of representation and concept. The intuitive and the logical elements are boths indispensable to it and both are bound together with unseverable link." [18] Jadi senada dengan Hamka, bagi Croce sejarah merupakan "penilaian individual" (individual judgment) yang memerlukan intuisi dan logika. Intuisi di sini adalah akal sehat, sedangkan logika adalah keteraturan berpikir yang didasarkan kepada silogisme.

Menarik dikemukakan bahwa dalam polemiknya dengan Parlindungan, Hamka memperjelas posisinya menyangkut pentingnya logika dalam pemahaman tahun-tahun terjadinya peristiwa sejarah. Parlindungan mengklaim bahwa metode sejarah yang digunakannya didasarkan kepada system sejarah Max Weber yang "tidak ada tempat tempat untuk dongeng2 kake2 tua, yang tanpa angka2 tahunan. Akibatnya: buku ini (Tuanku Rao, pen.) selaku buku sejarah menjadi bersifat historis exact, sama saja exactnya seperti suatu Buku Aljabar." Bagi Parlindungan yang penting adalah angka dan tahun, sedangkan bagi Hamka angka dan tahun itu tidak ada artinya jika tidak diselesaikan dengan logika:

bagi saya angka tahunan bukan exact, malahan barang mati jika tidak diselesaikan dengan logika. Dalam Tuanku Rao terdapat berpuluh-puluh angka tahunan, tetapi menjadi hancur laksana bukit salju kena panas setelah diuji dengan logika atau peralatan premis. (kursif ditambahkan) [19]

Dalam penilaian Hamka, jikapun Max Weber memandang penting sekali angka dan tahun dalam sejarah, akan tetapi kronologi peristiwa sejarah berdasarkan angka dan tahun yang disusun Parlindungan sama sekali tidak logis, sehingga Hamka menyimpulkan bahwa buku Parlindungan "sama sekali tidak memakai system Max Weber, sehingga buku ini banyak dongeng, atau menyerupai cerita 1001 malam." [20]

Dalam bagian lain secara sepintas Hamka mengemukakan system penulisan sejarah yang digunakan oleh sejarawan Muslim. Menurut Hamka, penyusunan sejarah menurut ahli-ahli sejarah Islam dapat dikelompokkan ke dalam dua macam:

[Pertama] Mengumpulkan segala fakta walaupun dari mana datangnya. Tidak peduli apakah fakta itu masuk akal atau tidak. Yang perlu dijaga ialah dari mana riwayat itu diterima. Pelopor dari penyusunan sejarah semacam ini ialah Ibnu Hisyam. [Yang kedua] Menilai fakta dan memberikan opini sendiri, sesudah fakta itu dikumpulkan. Inilah sistem Ibnu Khaldun." [21]

Hamka menjelaskan bahwa sistem Ibnu Hisyam mulai tumbuh sejak timbulnya ilmu hadis; menjaga sanad dan matan, mengaji siapa yang merawikan dan bagaimana nilai terhadap pribadi yang merawikan itu; adakah dia dapat dipercaya (tsiqqat) atau pembohong (kazzab) atau curang (mudallas) dan selanjutnya. Lalu memakai sanad itu ditiru untuk sejarah. Cara ini diteruskan oleh Muarrikh (ahli-ahli sejarah) sesudahnya. Ini juga yang dituruti jejaknya oleh Al-Masu'di dalam kitabnya Murujududz-zahab. Namun kemudian sistem Ibnu Khaldun inilah yang dijadikan pedoman dalam penyusunan sejarah, sampai menjalar ke Barat. Bahkan Arnold Toynbee dengan bukunya yang besar Philosophy of History (Filsafat Sejarah) menghakui terus terang bahwa dia merasa dirinya jadi murid Ibnu Khaldun.[22] Hamka sendiri tidak mengungkapkan prefer- 
ensinya secara terbuka di antara kedua cara penyusunan sejarah itu. Namun dari pengamatan penulis terhadap cara Hamka menilai fakta-fakta yang dikemukakan oleh Parlindungan, maupun dalam pembahasannya tentang peran hadis dalam sejarah (akan dibahas di bagian berikut), Hamka tampakanya lebih condong kepada penyusunan sejaran menurut system Ibnu Khaldun, yaitu "menilai fakta dan memberikan opini sesudah fakta itu dikumpulkan."

Lalu apa kegunaan ilmu sejarah menurut Hamka? Jawaban mengenai ini dapat diketahui dari tafsir Hamka terhadap surat Ali Imran ayat 104-109 tentang pentingngya dakwah dalam Islam. Menurut Hamka untuk suksesnya dakwah seorang juru dakwah wajib memiliki sejumlah syarat, dan salah satu syarat penting yang disebutkan Hamka adalah seorang juru dakwah.

Wajib berpengetahuan tentang pokok dan sumber ilmu sejarah yang umum; supaya mengetahui dari mana sumber kerusakan akhlak dan timbulnya adat-istiadat yang mengganggu kecerdasan berpikir. Dengan demikian apabila dia melakukan dakwah dia tidak berlaku seram, dengan memberantas adat kebiasaan ataupun hal yang dipandangnya bid'ah, sebelum dia mengetahui apa sebab musababnya dan dari mana asal usulnya. Kata-kata yang diucapkan dengan latar belakang pengetahuan yang demikian, sangat besar pengaruhnya kepada orang yang diseru, sehingga orang-orang yang diseru itu bisa dipindahkan dari satu keadaan kepada keadaan yang lain. Itulah sebabnya maka Al-Quran penuh dengan berita-berita tarikh. (Kursif ditambahkan)[23]

Dari pernyataan ini dapat disimpuilkan bahwa dalam pandangan Hamka para juru dakwah hendaknya melek sejarah ("bepengetahuan tentang pokok dan sumber ilmu sejarah yang umum") sehingga dakwah yang mereka lancarkan dapat menimbulkan transfromasi sosial ("orang-orang yang diseru bisa dipidahkan dari satu keadaan kepada keadaan lain"). Ini mengisyaratkan bahwa sejarah tidak dipelajari semata-mata sebagai ilmu melainkan sebagai 'ibrah, sebagaimana dibahas pada bagian berikut.

\section{B. Sejarah sebagai ‘Ibrah}

Tujuan belajar sejarah menurut konsep Islam adalah untuk memetik pesan moral atau 'ibrah. Pendapat Hamka mengenai hal ini dapat dilacak dalam Tafsir Al-Azhar sewaktu menjelaskan makna dari kisah-kisah dalam Al-Quran. Pada bagian pengantar kitab tafsir tersebut Hamka menjelaskan bahwa selain mengandung masalah hukum dan doktrin, Al-Quran mengandung kisah-kisah dan cerita-cerita masa lampau.[24] Di dalamnya banyak disebutkan perjuangan nabi-nabi dan rasul-rasul Allah dalam menegakkan paham tauhid dan soal-jawab di antara mereka dengan umat yang mereka datangi. Maksud dari segala kisah itu, termasuk cerita panjang seluruh surat seperti kisah Nabi Yusuf, bukanlah kisah itu sendiri melainkan isi pengajaran dan perbandingan (i'tibar) yang ada di dalamnya. Cara penafsirannya ialah satu bagian melengkapi bagian yang lain. Misalnya kisah perjuangan Musa, kita dapat mengetahui keadaan Musa sejak baru lahir sampai seluruh tingkat perjuangan dengan menafsirkan satu bagian dengan bagian yang lain. Namun untuk perincian lebih jauh, berbeda dengan hukum dan doktrin yang perinciannya banyak terdapat dalam hadis yang sahih, perincian kisah- 
kisah ini dalam hadis yang sahih sedikit sekali. Memang banyak sekali riwayat-riwayat yang berisi dongeng-dongeng Israiliyat yang tidak masuk akal menyangkut kisah-kisah dalam Al-Quran namun karena Islam menghormati kemurnian akal maka riwayatriwayat semacam itu dibatalkan saja.[25] Bahkan Hamka bersedia dituduh keluar dari "Ahlus Sunnah Waljamaah" kalau sekiranya membatalkan riwayat-riwayat yang tidak masuk akal itu dipandang salah oleh golongan yang menjadi budak dari tafsir semacam itu.[26]

Karena itu menurut Hamka jauh lebih aman jika ayat-ayat yang berkenaan dengan kisah-kisah itu dituruti sebagaimana adanya dalam Al-Quran saja, ditambah dengan sedikit analisa menurut tanggapan sendiri, dengan catatan bahwa analisa itupun barangkali benar atau salah. Sebab, lanjut Hamka, yang dimaksudkan dengan segala kisah itu bukanlah bukanlah perincian kisah melainkan sebagai i'tibar sebagaimana disebutkan dalam Al-Quran surat Yusuf ayat 111:

Artinya: "Sesungguhnya pada kisah orang-orang itu terdapat pengajaran bagi orang-orang yang mempunyai inti-fikiran; bukanlah dia dongeng yang dibuatbuat, melainkan membenarkan apa yang telah terdahulu daripadanya dan penjelasan bagi segala sesuatu, petunjuk dan rahmat untuk kaum yang beriman".

Menurut Hamka, ayat ini begitu jelas bahwa yang dimaksudkan Tuhan menerangkan kisah-kisah itu sebagai wahyu bukanlah untuk dongeng yang dibuatdibuat, artinya bukan cerita roman atau mitos laksana cerita Ramayana dan Mahabarata.[27] Pendapat Hamka ini sejalan dengan pendapat sejarawan kontemporer dari American University of Beirut, Tarif Khalidi, yang mengungkapkan bahwa "Qasas is contrasted with asatir, which are mere fables or legends, false or devoid of moral." [28] Menrut Khalidi selanjutnya, pengggunaan ungkapan "Kami kisahkan kepadamu cerita terbaik" dalam Al-Quran mengandung arti suatu ontology terpilih berdasarkan akurasi faktual dan nilai didaktis dari setiap kisah. Dalam setiap kisah Al-Quran, kejadiankejadian mencapai signifikansi moral dari 'aqibah atau hasil yang ditimbulkannya dan 'aqibah itu sekaligus merupakan pesan moral atau 'ibrah dari kisah tersebut. Pesan moral atau 'ibrah dari narasi sejarah di kemudian hari menjadi kata kunci dalam historigrafi Islam.[29] Dengan demikian, Al-Quran menggunakan istilah al-qasas untuk sejarah, namun demikian sejarawan bukan al-qussas, "tukang cerita," karena narasi sejarah yang ditulis oleh sejarawan didasarkan kepada data dan fakta untuk dijadikan pelajaran atau 'ibrah bagi generasi selanjutnya.

Bagaimana mengungkap pesan moral dari kisah Al-Quran, dapat dicontohkan dalam tafsir Hamka terhadap Ashabul Kahfi.[30] Menurut Hamka banyak riwayat tentang mereka sebelum turunnya Al-Quran yang diceritakan dari mulut ke mulut dari yang tua ke yang muda sehingga tidak kurang tidak ditambah dengan dongeng atau cerita karangan sendiri yang kadangkala dimasukan ke dalam tafsir. Akan tetapi jika dibaca langsung ayat-ayat yang diwahyukan Tuhan dan kisah itu dibersihkan menurut aslinya, maka tampaklah pengajaran yang mendalam untuk "menjadi perbandingan bagaimana tujuh orang yang tertidur di goa itu memegang teguh keyakinan hidupnya biarpun untuk itu mereka harus memisahkan diri dari masyarakatnya yang tidak mereka setujui itu." [31] 
Dalam Surat Kahfi 22 Tuhan juga mengisahkan bagaimana dikemudian hari orangorang berbeda pendapat mengenai bilangan Ashabul Kahfi-entah bertiga, berlima, atau bertujuh. Namun dalam menghadapi pertikaian pendapat itu sikap seorang Muslim sebaiknya menyerahkan urusan itu kepada Tuhan, sebagaiman dinyatakan penghujung ayat 22 surat Kahfi:

Artinya: "Katakanlah: Tuhanku yang lebih tahu dengan jumlah mereka; tidak ada yang mengetahui berapa mereka kecuali sedikit. Oleh karena itu janganlah turut bertengkar tentang mereka melainkan perbantahan yang jelas, dan tidak usahlah engkau bertanya tentang mereka itu kepada kepada seorang juapun".

Menurut Hamka, ungkapan "tidak ada yang mengetahuinya kecuali sedikit" itu tentulah maksudnya orang yang hidup pada masa itu, yang turut ziarah ke dalam goa itu, termasuk raja negeri itu, yang sekarang sudah tidak ada lagi, atau termasuk juga Rasul S.A.W sendiri. Akan tetapi Rasul sendiri dilarang Tuhan untuk mempertengkarkan bilangan mereka sebab hal itu hanya menghabiskan waktu belaka, sebab menurut Hamka "ilmunya tidak berdasarkan kepada penyelidikan (riset) tertentu," sehingga kalau dipertengkarkan juga tidak akan berkesudahan. Sedangkan ungkapan "janganlah turut bertengkar tentang mereka melainkan perbantahan yang jelas" menurut Hamka merupakan tuntunan bagi Rasulullah dan umat beriman agar tidak membuang-buang waktu untuk mempertengkarkan hal-hal yang "tidak ada alasan, pertahanan dan buktibuktinya," akan tetapi Hamka menegaskan bahwa "bertengkar atau bertukar pikiran tidak dilarang asalkan soalnya dapat diselesaikan dengan baik untuk mendudukan kebenaran." [32] Kebolehan bertukar pikiran bahkan berdebat tentang sejarah demi "mendudukan kebenaran" tentulah tugas sejarawan yang memiliki peralatan metodologis untuk merekontruksi sejarah secara benar. Hanya berdasarkan pemahaman sejarah yang benar seseorang dapat memetik pesan moral secara sah dari sejarah guna dijadikan pedoman dalam menjalani kehidupan.

Peran sentral 'ibrah dalam konsep pendidikan sejarah Hamka, tampaknya dipengaruhi oleh filsafat sejarah Ibnu Khaldun. Menurut Ahmad Tafsir, Ibnu Khaldun membuat judul bukunya Kitab al-'Ibar dan bukan "Kitab al-Tarikh" maksudnya tiada lain untuk lebih menonjolkan 'ibrah agar manusia dapat "belajar dari sejarah." Menurut Tafsir selanjutnya,

Filsafat sejarah dalam dalam pengertian sederhana adalah tinjauan terhadap peristiwa-peristiwa historis secara filosofis untuk mengetahui faktor-faktor esensial yang mengendalikan perjalanan periswa-peristiwa tersebut untuk kemudian menetapkan hukum-hukum umum yang tetap yang mengarahkan perkembangan bangsa-bangsa dan negara dari generasi ke generasi. Hukum umum inilah yang menjadi pelajaran. [kursif ditambahkan] [33]

Memang dalam menulis buku-buku sejarahnya, Hamka cenderung menggunakan gaya bercerita (sejarah sebagai narasi), namun itu hanyalah gaya yang dipilih untuk memudahkan sampainya pesan moral kepada pembacanya. Dalam karya-karya sejarah Hamka, kita tidak akan menemukan suatu eksposisi mengenai "hukum-hukum sejarah" sebagaimana Ibnu Khaldun-karena ini adalah tugas filsuf sejarah-melainkan akan mendapatkan suatu narasi yang hidup mengenai peristiwa-peritiwa yang dipaparkann- 
ya, dan karena narasi sejarah itu dimaksudkan untuk menyampaikan 'ibrah maka membaca karya Hamka akan membuat kita merenung mengenai apa yang terjadi sebenarnya dan bagaiaman seharus kita berbuat di masa depan.

Suatu contoh yang sangat menarik bagaimana Hamka memetik pesan moral dari sejarah untuk dijadikan pedoman dalam menghadapi masa depan, adalah sebuah syair cukup panjang "Di Atas Rertuntuhan Melaka." Syair ini digubah Hamka secara spontan ketika berdiri terpesona di atas benteng St. Paul memandang perairan Selat Malaka. Ilham yang datang tiba-tiba itu ditulisnya secara cepat dengan "steno" huruf Arab yang di kemudian hari diperbaiki dan diterbitkan dalam majalah Fajar Asia di zaman Jepang. Berikut ini penulis salinkan syair tersebut secara utuh, dengan menambahkan nomor bait di sampingnya untuk memudahkan rujukan penafsiran.

\section{Diatas Reruntuhan Melaka Lama[34]}

1 Diatas runtuhan Malaka lama Penyair termenung seorang diri Ingat Melayu kala jayanya Pusat kebesaran nenek bahari

2 Diatas munggu yang ketinggian Penyair duduk termenung seorang Jauh pandangku ke pantai sana Ombak memecah diatas karang

3 Awan berarak mentilau bernyanyi Murai berkicau, bayu merayu Kenang melayang ke alam sunyi Teringat zaman yang lama lalu

4 Sunyi dan sepi, hening dan lingau Melambai sukma, melenyai tulang Arwah Hang Tuah rasa menghimbau Menyeru umat tunduk ke Tuhan

5 Disini dahulu alat kebesaran Adat resam teguh berdiri Duduk semayam yang dipertuan Melimpah hukum segenap negeri

6 Disini dahulu Laksamana Hang Tuah Satria moyang Melayu jati Jaya perkasa, gagah dan mewah "Tidak Melayu hilang di bumi"

7 Disini dahulu payung terkembang Megah Bendahara Seri Maharaja Bendahara yang cerdik tumpuan dagang Lubuk budi laut bicara 
8 Penyair menghadap kelaut lepas Selat Malaka tenang terbentang Awan berarak riak menghempas Mentari turun rembanglah petang

9 Wahai tuan Selat Malaka Mengapa tuan berdiam diri Tidakkah tahu diuntung hamba Hamba musafir datang kemari

10 Di mana Daulat Yang dipertuan Mana Hang Tuah, mana HangJebat Mana Bendahara Johan Pahlawan Bukankah jelas didalam babad

11 Namanya tetap jadi sebutan Bekasnya hilang payah mencari Hanya sedikit bertemu kesan Musnah dalam gulungan hari

12 Hanyalah ini bekas yang tinggal Umat yang lemah terkatung-katung Hidup menumpang tanah terjual Larat wai larat dipukul untung

13 Adakah ini bekas peninggalan Belahan diriku umat Melayu Lemah dan lunglai tiada karuan Belahan diriku umat Malayu

14Jauh didarat penyair melihat Gunung Ledang duduk termangu Tinggi menjulang hijau dan dahsyat Hiasan hikayat nenekku dulu

15 Didalam kuasyik merenung gunung Di dalam kemilau panas 'kan petang Tengah khayal dirundung menung Rasanya ada orang yang datang

16 Penyair hanya duduk sendiri Tapi keliling rasanya ramai Bulu romaku rasa berdiri Berbuah warna alam yang permai

17 Ada rasanya bisikan sayu Hembusan anggin di Gunung Ledang Entah puteri datang merayu 
Padahal beta bukan meminang

18 Bukanlah hamba Sultan Melaka Jembatan emas tak ada padaku Kekayaan hanya syair seloka Hanya nyanyian untuk bangsaku

19 Tiba-tiba terdengar puteri berkata Suaranya halus masuk kesukma; Maksudmu tuan sudahlah nyata Hendak mengenang riwayat yang lama

20 Bukan kuminta jembatan emas Tapi nasihat hendak kuberi Kenang2an zaman yang lepas I'tibar cucu kemudian hari

21 Sebelum engkau mengambil kesimpulan Sebelum Portugis engkau kutuki Inggeris Belanda engkau cemarkan Ketahui dahulu salah sendiri

22 Sultan Mahmud Syah mula pertama Meminang diriku ke Gunung Ledang Segala pintaku baginda terima Darah semangkok takut menuang

23 Adakan cita akan tercapai Adakan hasil yang diingini Jika berbalik sebelum sampai Mengorbankan darah tiada berani

24 Apakah daya Datuk Bendahara Jikalau Sultan hanya tualang Memikir diri seorang saja Tidak mengingat rakyat yang malang 25 Sultan Ahmad Syah apalah akalnya Walaupun baginda inginkan syahid Mu'allim Makhdum lemah imannya "Di sini bukan tempat Tauhid"

26 Bendahara tua Paduka Raja Walaupun ingin mati berjuang Bersama hilang dengan Melaka Anak cucunya hendak lari pulang

27 Berapa pula penjual negeri Mengharap emas perak bertimba Untuk keuntungan diri sendiri 
Biarlah bangsa menjadi hamba

28 Ini sebabnya umat kan jatuh

Baik dahulu atau sekarang Inilah sebabnya kakinya lumpuh

Menjadi budak belian orang

29Sakitnya bangsa bukan diluar

Tetapi terhunjum di dalam nyawa

Walau diobat walau ditawar

Semangat hancur apalah daya

30 Janjian Tuhan sudah tajalli

Mulailah umat yang teguh iman

Allah tak pernah mungkirkan janji

Tarikh riwayat jadi pedoman

31 Tidaklah Allah mengubah untung

Suatu kaum dalam dunia

Jika hanya duduk termenung

Berpeluk lutut berputus asa

32 Malang dan mujur nasibnya bangsa

Turun dan naik silih berganti

Terhenyak lemah; naik perkasa

Bergantung atas usaha sendiri

33 Riwayat yang lama tutuplah sudah Apakah guna lama terharu Baik berhenti bermenung gundah Sekarang buka lembaran baru

34 Habis sudah madahnya puteri Ia pun gaib khayalpun hilang Tinggal penyair seorang diri

Di hadapan cahaya jelas membentang

35 Pantai Melaka kulihat riang

Nampaklah ombak kejar mengejar

Bangunlah tuan belahan sayang

Seluruh Timur sudahlah sadar

36 Bercermin pada sejarah moyang

Kita sekarang mengubah nasib

Di zaman susah atau pun riang

Tolongan tetap dari yang Gaib

37 Bangunlah kasih umatMelayu

Belahan asal satu turunan 
Bercampur darah dari dahulu

Persamaan nasib jadi kenangan

38 Semangatyang lemah dibuang jauh

Jiwa yang kecil kita besarkan

Yakin percaya, iman pun teguh

Zaman hadapan, penuh harapan

39 Bukanlah kecil golonganmu tuan

Tujuh puluh juta Indonesia

Bukan sedikit kita berteman

Sudahlah bangun bumi Asia

40 Kutarik napas, kukumpul ingatan

Aku pun tegak dari renungku

Jalan yang jauh aku teruskan

Melukis riwayat safhat hidupku

41 Kota Melaka tinggallah sayang

Beta nak balik ke Pulau Perca

Walau terpisah engkau sekarang

Lambat launnya kembali pula

Walaupun luas watan terbentang

Danau Meninjau terkenang jua

Pada empat bait pertama Hamka melukiskan keterpesonaannya dengan keindahan perairan Selat Melaka tempat berjaya "nenek bahari" (bait 2) yang membawa angannya ke zaman lampau. Terbayang kegagahberanian laksamana Hang Tuah yang "menyeru umat tunduk ke Tuhan" (bait 4) dan terkenal dengan sumpahnya "tidak Melayu hilang di bumi" (bait 6). Terbayang kemegahan Bendahara Seri Maharaja "tumpuan budi laut bicara" (bait 7), kepahlawanan Hang Jebat dan Bendahara Johan Pahlawan. Semua tokoh yang mengukir kerajaan Melayu lama itu tercantum dalam "babad" (bait 10), namun walaupun "namanya tetap disebut" akan tetapi "bekas jejaknya" hilang "musnah dalam gulungan hari" (bait 11). Yang tersisa sekarang hanyalah "umat yang lemah terkatung-katung" (bait 12), "lemah dan lunglai tiada karuan" (bait 13), sungguhpun "Gunung Ledang" masih tegak perkasa seperti sediakala (bait 14).

Kontras antara kejayaan masa lalu dan kemalangan masa sekarang, membawa Hamka pada perenungan mengenai penyebab kemunduran sejarah Melayu lama. Di tengah perenungan yang mendalam itu (bait 15-16) membersit "bisikan sayu" (bait 17) dari reruntuhan sejarah Melayu Lama yang diibaratkan dengan "seorang putri" (bait 1519) yang ingin memberi "nasehat" mengenai "zaman yang lepas" itu sebagai "i'tibar cucu kemudian hari" (bait 20).

I'tibar yang harus dipetik dari keruntuhan Melayu Lama itu, pertama-tama sekali janganlah terburu-buru menyalahkan pihak penjajah seperti Portugis, Inggris, atau Belanda, akan tetapi "ketahui dahulu salah sendiri" (bait 21): Kesalahan itu terdapat 
pada sultan yang hanya menikmati kemewahan istana tapi "darah semangkok takut menuang" (bait 22) yang ketika melawan musuh asing sudah "berbalik sebelum sampai" karena "mengorbankan darah tiada berani" (bait 23). Di puncak kejayaan itu Sultan hanya "hidup tualang," "memikirkan diri sendiri," dan "tidak mengingat rakyat yang malang," sehingga pejabat sepintar apapun dibuat tak berdaya memperbaiki keadaan (bait 24). Akibat lebih jauh, para panglima dan prajurit mengalami demoralisasi, "lemah imannya," karena "di sini bukan tempat Tauhid" (bait 25), sementara para bangngsawan anak cucu kerajaan hanya menyelamatkan diri sendiri di kala musuh menyerbu (bait 26). Dalam keadaan demikian, bermunculan para "penjual negeri" atau pengkhianat yang demi keuntungan diri sendiri tega "membiarkan bangsanya menjadi hamba" bagi pihak asing (bait 27).

Itulah penyebab utama keruntuhan Melalyu Lama, bahkan ini pula yang akan menjatuhkan umat yang berikutnya: "Ini sebabnya umat kan jatuh, dari dahulu sampai sekarang" (bait 28). Jadi, penyebab kejatuhaan dalam sejarah adalah penyakit yang dalam diri sendiri yang bersumber dari kelemahan iman (bait 29) padahal Allah sudah menjanjikan bahwa iman yang teguh itulah sumber kekuatan sejarah (bait 30). Kita tidak boleh putus asa merenung nasib melainkan bangkit mengubah sejarah dengan terlebih dahulu "mengubah diri sendiri" (bait 31) karena "malang dan untungnya suatu bangsa tergantung usaha sendiri" (bait 32). Walaupun tidak disebutklan, jelas sekali bahwa kesimpulan akhir dari syair tersebut didasarkan kepada semangat Al-Quran surat Ar-Ra'd ayat 11:

Artinya: "Sesungguhnya Allah tidak akan mengubah nasib suatu kaum sebelum kaum itu mengubah dirinya sendiri."

Berdasarkan syair ini dapat disimpulkan, bahwa bagi Hamka tujuan utama dari kajian sejarah adalah untuk i'tibar, guna memetik pelajaran dari perjalanan jatuh bangunnya umat-umat yang terdahulu. Sejarah sebagai i'tibar diperlukan untuk menata masa depan ke arah yang lebih baik: "bercermin pada sejarah moyang, kita sekarang mengubah nasib" (bait 36). Bagi Hamka, kejayaan masa lalu itu bukan untuk dipuja-puja sebagaimana kejatuhan masa lalu itu tidak untuk dicela-cela, melainkan untuk diambil mana yang baik dan dibuang mana yang buruk. Dengan bekal pengetahuan sejarah itu setiap Muslim diharapkan meneruskan jejak langkah mengukir sejarah hidupnya sendiri, sebagaimana tekad Hamka untuk dirinya pada bait 40 :

Kutarik napas, kukumpul ingatan

Aku pun tegak dari renungku

Jalan yang jauh aku teruskan

Melukis riwayat safhat hidupku

Dari bait ini tampak jelas bahwa Hamka tidak "berkhotbah" untuk orang lain tentang pesan moral sejarah tapi melupakan dirinya sendiri, dia yang pertama-tama harus mengambil pelajaran dari pesan moral tersebut bagi dirinya (ujung bait 40). Dia ingin melanjutkan jejak sejarah tokoh-tokoh Melayu dari ranah semenanjung itu dalam ranah Minangkabau di pulau Perca dengan danau Maninjaunya yang indah (bait 41).

Demikianlah, bagi Hamka belajar sejarah tidak untuk ilmu semata-mata melainkan untuk memetik pesan moral atau 'ibrah. Dengan kata lain sejarah harus dipelajri sebagai 
ilmu namun dengan tujuan untuk memperoleh 'ibrah. Sudah tentu sejarah juga dapat digunakan untuk tujuan lain, entah sebagai hiburan, atau sebagai pembentuk jati diri bangsa, sebagaimana diajukan oleh para pakar pendidikan sejarah sekuler, akan tetapi bagi umat Muslim sejarah diperlukan sebagai i'tibar atau menarik pesan moral. Kemampuan menarik i'tibar dari sejarah menjadi ciri menonjol dalam kapasitas Hamka sebagai sejarawan, sebagaimana diakui oleh sejarawan Taufik Abdullah bahwa "sebagai pengkaji sejarah yang kritis, Hamka tidak saja menjadikan masa lalu hidup kembali melainkan juga berhasil menemukan pesan-pesan moral yang dikandung sejarah untuk masa kini." [35]

\section{Metode Pengajaran Sejarah}

Hamka pada dasarnya adalah seorang otodidak yang selalu belajar sepanjang hayat dalam berbagai bidang yang diminatinya. Dari uraian Bab III tentang riwayat hidup Hamka yang dibahas dari framing bagaiamana beliau membentuk dirinya di bidang sejarah, dapatlah dipetik sejumlah kata kunci yaitu "minat", "efikasi-diri", "mengamati", "membaca", dan "menulis". Jika cara belajar ini dipadukan dengan pendekatan berpikir historis yang terpantul dalam karya sejarahnya, maka konsep pendidikan sejarah Hamka dapat dirumuskan sebagai upaya memupuk minat dan efikasi diri siswa dalam berpikir historis melalui kegiatan mengamati, membaca, dan menulis tentang sejarah.

\section{Minat terhadap Sejarah}

Hamka adalah peminat sejarah di sepanjang hayatnya. Sejak sekolah di madrasah hingga masa tuanya Hamka terus menggumuli kajian sejarah secara mandiri sehingg bahan-bahan sejarah ini yang lebih banyak muncul mewarnai uraian dakwahnya. Maka kata kunci pertama mengenai konsep pendidikan sejarah Hamka adalah minat. Minat inilah yang pertama-tama harus ditumbuhkan dalam pendidikan sejarah. Bagaimana caranya menumbuhkan minat siswa kepada sejarah?

Pada kasus Hamka, minat itu tertanam dan tumbuh secara alamiah karena sejak usia dini dia diemong oleh kakeknya dengan seni cerita lokal Minangkabau (kaba) sebagai pengantar tidur; ketika sudah mulai bisa membaca dia dibelikan ayahnya bukubuku cerita; sejak kanak-kanak dia senang mendengar orang "bakaba"—suatu seni bercerita yang diramu dari kisah-kisah nyata rakyat Minangkabau; dan satu-satunya guru yang menarik baginya adalah Engku Labay El-Yunusiyah karena menyelami jiwa anak dan suka menghajar dengan cara bercerita. Singkatnya, dalam usia formatifnya Hamka gemar dengan "seni cerita." Tampaknya kegemaran inilah yang menimbulkan minat Hamka kepada sejarah dan sastra sehingga sewaktu belajar di madrasah hanya tarikh dan 'arudh pelajaran yang disukainya. Minat Hamka ini muncul secara alamiah tanpa ada yang mengarahkan secara khusus karena orang tua dan lingkungan sekitarnya lebih mengharapkan dia untuk mendalami agama. Orang tuanya sendiri kadangkala mengungkapkan kekecewaannya karena Hamka kecil lebih tertarik kepada cerita ketimbang agama. Ketidakmampuan guru untuk memahami minat dan bakat 
anak inilah yang disesali Hamka dalam sistem pendidikan yang pernah dilaluinya dan tidak ditamatkannya itu.

\section{Efikasi Diri}

Hamka adalah seorang otodidik yang selalu belajar dan mengembangkan dirinya sepanjang hayatnya. Dalam refleksinya terhadap kehidupan masa remajanya, Hamka mengakui dalam dirinya "tersimpan sesuatu yang tidak pernah mati, yang tiada pernah padam. Yang didalam seluruh hidup yang telah dilaluinya, senantiasa mendorongnya untuk maju. Yaitu tampang atau bakat "percaya kepada diri sendiri" (kursif dari Hamka).[36] Dan walaupun "tumbuh capuk dimukanya, dan kebencian orang kiri kanan, menyebabkan tumbuh suatu yang lain, yaitu menimbulkan, membangkitkan diri dari segi yang lain. Membaca, belajar, mencatat apa2 yang dirasanya penting. Kadang2 'ayat2 Qur'an' pun disalinnya kedalam notnya (kursif ditambahkan)."[37] Dalam bahasa psikologi kognitif, kepercayaan kepada kemampuan diri sendiri dalam menuntaskan tugas-tugas belajar disebut "efikasi-diri dalam belajar secara mandiri" (self-efficacy in self-regulated learning). Efikasi-diri ini penting dalam proses belajar, terutama sekali dalam belajar tanpa guru. Dalam kaitan ini dengan efikasi diri ini Hamka tidak menyarankan orang untuk menjadi otodidak seperti dirinya, melainkan dengan pertama-tama belajar melalui bantuan guru dan kemudian belajar sendiri tanpa bantuan guru:

Menurut penuturan Hamka, pada masa bertugas di Makssar inilah dia benar-benar belajar sendiri menjadi "guru" dan "muballigh" tanpa panduan siapapun serta menyadari bahwa dirinya benar-benar harus belajar lebih banyak lagi mengenai konten apa yang harus diajarkan dan disampaikan. Demikianlah, pulang dari Makssar dalam umur 26 tahun "barulah" Hamka minta belajar kepada ayahnya, dan sang ayah yang sudah menyadari minat anaknya pada sejarah dan filsafat serta kemampuannya belajar secara mandiri, hanya membimbingnya belajar Usuhul Fikih dari Mantik karena "dengan bekal kedua ilmu itu engkau tidak akan tersesat jalan" dalam belajar sendiri. Hanya dengan modal kepercayaan diri plus penguasaan Ushul Fikih dan Mantik inilah Hamka terus menerus belajar sendiri apa yang diminatinya dan tanpa ragu mengungkapkan hasil belajarnya melalui lisan dan tulisan kepada audiens masyarakat luas. Inilah rahasia keberhasilannya yang dalam usia 28 mulai memimpin Pedoman Masyarakat di Medan (1936-1942) sehingga dia semakin termashur sebagai penulis. Dalam refleksinya terhadap perjalanan hidupnya yang dimulai dari putus sekolah dan terus belajar hinga mencapai prestasi ini, pada tahun 1940 Hamka menulis:

Setelah saya tak lulus di bangku sekolah masuklah saya ke sekolah hidup, atau karena keluar dari sekolah karena tak berdiploma, saya masuklah ke sekolah hidup sejak dari kelas yang pertama, 20 tahun yang lalu. Adapun teman2 saya yang pintar2 itu, sejak tamat dari sekolah dengan mengantongi segulung kertas, langsung berhenti, mereka tidak pernah hendak belajar lagi, yang dibanggakannya sekarang ialah 
kepintarannya dan kebodohan saya 20 tahun yang lalu. Mereka tidak insaf perubahan hidup manusia di dalam masa 20 tahun.[38]

Dari uraian di atas tampaklah, bahwa dengan semangat "efikasi diri untuk belajar mandiri" Hamka berhasil membentuk dirinya dalam bidang yang diminatinya. Hal ini juga berlaku untuk bidang sejarah: Hamka mengkaji sejarah dengan mengamati, membaca, dan menulis pertama-tama secara intutif dan kemudian secara logis setelah menguasai mantik. Hanya intuisi dan logika inilah "peralatan metodologis", jikapun dapat disebut demikian, yang dimiliki Hamka dalam belajar sejarah.

\section{Mengamati}

Hamka adalah pengamat yang tajam sejak masa kecil. Sama seperti anak-anak lainnya, sedari kecil Hamka suka mengamati apa yang menarik perhatiannya. Hanya berbeda dengan anak-anak lainnya, pengamatan Hamka itu berbekas dalam ingatan dan kemudian mendorongnya untuk mencari tahu lebih banyak. Mungkin perilaku "tualang" sebagaimana dikisahkan dalam riwayat hidup di masa kecilnya telah memupuk dan mempertajam pengamatan Hamka: ketika tinggal dengan neneknya di kampung, pasti minta ikut menangkap ikan ke danau yang sebetulnya dimarahi ayahnya jika ketahuan; ketika tinggal di Padang Panjang, pergi ke sana kemari bergaul dengan "parewa" (preman kampung), menonton pacu kuda, bermain silat, berkelahi; semasa tinggal di asrama Parabek Buktinggi, seluruh nagari disekitarnya mejadi jelajahannya, asyik berlama-lama menikmati pidato adat para pangulu atau cerita para tukang kaba sampai-sampai dia pintar menirukannya. Pada Hamka pengamatan ini menjadi proses pembelajaran kreatif: pengamatan terhadap peristiwa tragis yang disaksikannya sendiri di masa kecil di kampung neneknya-seorang istri dibunuh suami lalu bunuh diri karena kisruh rumah tangga akibat keserakahan mertua-dan pengamatan terhadap cara orang bakaba, menghasilkan karya tulis kreatif berbahasa Minangkabau huruf Jawi, Si Sabariyah, yang dicetak sampai tiga kali dan didendangkan pula oleh para tukang kaba. Karya tulis kreatif ini dihasilkannya secara mandiri, hanya dengan mengamati dan mencobakan sendiri dalam usia yang masih belia 17 tahun tanpa bimbingan langsung dari guru. Keingintahuan pada lingkungan yang mendorongnya untuk melakukan perlawatan untuk mengamati dunia lain dari dekat dan hampir seluruh wilayah Nusantara dan dunia Melayu sudah pernah dilawatinya semenjak usia mudahnya. Diakuinya sendiri bahwa:

Menurut Hamka, pertanyaan berisi peringatan dalam ayat ini, menyuruh manusia untuk "menyalangkan mata, menyaringkan telinga, lihatlah dan dengarlah tentang manusia-manusia yang telah berlalu di dalam sejarah." [39] Walaupun anjuran pertama ayat ini ialah kepada kaum musyrikin Quraisy tetapi pesan umum ayat ini menurut Hamka “jadi rangsangan bagi seluruh manusia yang berakal supaya mengambil i'tibar dan perbandingan dari kaum yang telah musnah karena congkak, sombong, ingkar, dan tidak mau percaya." [40] Hamka mencontohkan peninggalan kerajaan Mesir yang telah sanggup mendirikan berbagai piramid, luxor, abu sinbel; kerajaan Athena yang telah runtuh; kaum Tsamud atau Madyan Shalih yang telah membuat negeri dan kota dalam bukit; penduduk Pompejus yang ditimbuni lahar gunung Vesuvius, semuanya menun- 
jukkan betapa kuatnya umat zaman dahulu kala namun runtuh juga yang bekas-bekas reruntuhannya masih dapat dilihat dan diperiksa sekarang untuk diambil pelajaran.

Pengamatan yang dilakukan Hamka sejak kecil di kampung halamnya, lalu diperluas melalui lawatan ke berbagai daerah di seluruh wilayah kepualauan Nusantara dan Melayu pada masa remaja dan dewasanya, kemudian uraian tafsir di masa tuanya tentang pentingnya "berjalan di muka bumi" dengan "menyalangkan mata, menyaringkan telinga, lihatlah dan dengarlah tentang manusia-manusia yang telah berlalu di dalam sejarah," tidak pelak lagi merupakan bagian penting dari konsep pendidikan sejarah Hamka yang untuk penyederhanaan kita sebut saja "pengamatan." Pengamatan sebagai kegiatan dalam pendidikan sejarah, dilakukan Hamka secara intuitif, dalam arti muncul dari minatnya dan ketertarikan kepada apa yang terjadi di lingkungan, yang dalam pepatah adat Minangkabau disebut "alam takambang jadi guru."

\section{Membaca}

Hamka adalah pembaca yang rakus sejak masa kecilnya hingga hari tuanya. Kita mengira mungkin minat bacanya tumbuh dalam tradisi keluarganya, mengingat bahwa sebagai ulama ayahnya memiliki "khutub khanah" dengan koleksi kitab yang banyak. Namun dari pembacaan terhadap kisah hidupnya, bukan kitab-kitab bahasa Arab itulah yang pertama kali merangsang, melainkan buku-buku cerita berbahasa Melayu yang dibelikan ayahnya ketika dia disunat dalam usia 7 tahun. Semasa sekolah, kitab-kitab Arab yang digunakan untuk pelajaran yang menarik baginya hanyalah yang menyangkut "syair" atau "tarikh." Di luar sekolah, Hamka lebih tertarik membaca roman-roman terbitan Balai Poestaka baik terjemahan maupun karangan penulis pribumi. Baru belakangan semasa di Mekkah Hamka membaca kitab-kitab berbahasa Arab, yang kemudian dilanjutkan dengan berlangganan kitab-kitab terbitan Mesir ketika beliau menjabat pemimpin umum Majalah Pedoman Masyarakat di Medan. Diakui Hamka, bahwa kesukaannya membaca roman-rpoman Balai Pustaka di masa remajanya, telah mengasah kepekaraan rasa bahasanya ke arah bahasa Indonesia "yang teratur dan indah." Dan kesukaannya membaca buku-buku terbitan Mesir, yang rata-rata berkaitan dengan roman dan kebudayaan, baik karya-karya asli penulis Arab seperti AlManfaluthi atau karya-karya terjemahan Arab dari penulis Barat seperti Shakespeare, telah memperkaya wawasannya sehingga dia tidak ketinggalan informasi sebagai pemimpin majalah. Sudah tentu sebagai ulama Hamka juga melahap kitab-kitab asli berbahasa Arab dalam berbagai cabang ilmu pengetahuan agama yang diminatinya, umpamanya tasawuf atau tarikh.

Sebagai peminat sejarah, sebagaimana tampak dalam kepustakaan bukunya Sejarah Umat Islam yang disusun selama 22 tahun (1939-1961) dapat dipastikan Hamka akrab dengan kitab-kitab tarikh klasik Islam seperti Sirah Ibnu Ishaq, Sirah Ibnu Hisyam, Tarikh al-rusul wa al-muluk Ath-Thabari, Al-bidāya wa an-nihāya fi at-tarīkh Ibnu Katsir, Kitab al-'ibar Ibnu Khaldun, Muruj adz-dzahab wa ma 'adin al-jawhar al-Mas'udi, dan Al-Mukhtashar fi akhbar al-basyar Abu al-Fida.' Selain itu beliau juga membaca kitab-kitab tarikh penulis kontemporer seperti Tarikh at-tamaddun al-Islami Jurji Zaidan, terjemahan Arab The Preaching of Islam Thomas W. Arnold, dsb. Untuk jilid IV buku 
Sejarah Umat Islam yang khusus membahas sejarah Islam di Nusantara, Hamka juga tampak akrab dengan historiografi tradisional dunia Melayu/Nusantara seperti Sejarah Melayu Tun Seri Lanang, Hikayat Raja-raja Pasai dari Sheikh Nuruddin Ar-Raniri, Tuhfatun Nafis Raja Ali Haji, dan Babad Gianti dari Mataram. Selain itu Hamka juga membaca bahan-bahan sejarah-kemungkinan berupa manuskrip-yang diperoleh langsung dari Seri Paduka Siak Seri Indrapura (1940), Sultan Trengganu (1955), Sultan Perak (1958), Aru Mapanyuki Raja Bone (1955), Raja Gowa (1956), Sultan Perak, dan Sultan Brunei (1960).

Dalam menyusun buku Dari Perbendaharaan Lama (1962) yang merupakan kumpulan artikel sejarah di Indonesia yang ditulis dalam Mingguan Abadi tahun 1955 sampai 1960, selain menggunakan historigrafi tradisional di atas Hamka mengakui juga membaca karya-karya orang Belanda. Dalam pengantarnya Hamka menuturkan bagaimana dia membaca sumber-sumber tersebut:

Orang bertanya kepada saya buku apa yang saya baca ketika saya menyusun "Dari Perbendaharaan Lama" ini, lalu saya katakan bahwa apa yang saya baca, selain bukubuku lama pusaka nenek moyang kita, yang setengahnya benar-benar dikeluarkan dari simpanan perbendaharaan lama, adalah buku-buku yang mereka baca juga. Perbedaannya hanya sedikit, yaitu bahwa saya melihat apa yang tidak mereka lihat. Sayapun membaca buku-buku catatan sarjana sejarah Belanda, namun setelah saya baca bukubuku itu, ternyata pula bahwa merekapun kadang-kadang tidak melihat apa yang saya lihat.[41]

Dari kutipan di atas terlihat bahwa Hamka tidak menelan begitu saja apa yang tertulis dari bacaannya, melainkan menelaah dan mengambil kesimpulan sendiri yang belum tentu sama dengan kesimpulan orang lain.

\section{Menulis}

Hamka adalah penulis yang produktif. Kegiatan menulis sudah dimulai sejak usia muda dan terus berlangsung sampai masa tua. Dapat dikatakan bahwa Hamka berkembang sejalan dengan perkembangan tulisannya. Untuk kepentingan analisis, kita akan membatasi perkembangan tulisan Hamka dalam usia 17-18 tahun (analog dengan rentang usia jenjang SLTA) dan usia 19-23 tahun (analog dengan rentang usia jenjang S1). Pada rentang usia jenjang SLTA, dalam usia 17 tahun (1925) Hamka menulis pidato-pidato dakwah yang dipublikasi dalam bentuk majalah Khatibul Ummah (3 nomor); dan dalam usia 18 tahun (1926) Hamka menulis dan memplikasikian karya kreatif Si Sabariyah yang didasarkan pada kisah nyata yang pernah disaksikan di masa kecil dan disajikan dalam bentuk kaba, genre sastra rakyat Minangkabau. Walaupun karya ini dicetak ulang hingga 3 kali, namun Hamka baru merasa diri benar-benar seorang "penulis" setelah memperoleh umpan balik positif dari 3 ulama, Dr. Syekh Rasul Amrullah (ayahnya), Dr. Syeikh Abdullah Ahmad, dan Syeikh Muhammad Jamil Jambek. Umpan balik positif itu diperoleh ketika ketiga ulama dalam suatu kesempatan sedang mau tidur siang di sebuah surau, dan salah seorang-Abdullah Ahmad-bertanya ingin tahu tentang Si Sabariyah yang dicetak ulang, lalu Hamka membacakannya dengan cara bertutur tukang kaba. Ketiga ulama mula-mula menyimak sambil tiduran, rupanya 
makin tertarik lalu duduk menyimak sampai buku itu selesai dibacakan dan ketiganya tidak jadi tidur siang. Hamka merasakan kebanggaan ayahnya, dan ketika meninggalkan mereka Hamka masih mendengar komentar kagum Syeikh Jambek, "ada-ada saja Datuk ini." Dalam teori efikasi-diri Bandura, seorang penulis menguat efikasi dirinya atau kepercayaan diri dalam kemampuan menulis jika memperoleh umpan balik positif dari audiensnya. Hal ini dialami oleh Hamka, sebagaimana ditulisnya sendiri dalam riwayat hidupnya: "Orang banyak sudah lama mengakuinya sebagai pengarang. Tetapi dirinya sendiri baru yakin bahwa dirinya memang pengarang setelah "tiga ulama" termasuk ayahnya menyukai "Si Sabariyah." Dipandang dari segi pedagogik, penguatan efikasi diri ini amat penting dalam masa pertumbuhan awal Hamka sebagai penulis yang masih dalam usia SLTA itu. Kendatipun yang ditulis bukan masalah agama, bahkan hanya karya kreatif dalam bentuk kaba, ketiga ulama besar itu tidak apriori menolak. Bahkan dengan gesture yang amat mendidik mereka bersedia menyimak sampai selesai dan tidak menyembunyikan kekaguman, suatu peristiwa langka yang sukar didapatkan sekarang, termasuk dalam sistem pendidikan formal.

Selanjutnya, pada usia 19-23 tahun yang analog dengan rentang usia jenjang S1, pada masa ini Hamka sepenuhnya menulis tentang masalah-masalah serius yang barangkali analog dengan tugas menulis akademik jenjang S1. Bedanya Hamka menulis tanpa panduan akademik, tapi dengan efikasi dirinya yang tinggi menulis masalahmaslaah yang sedang menjadi fokus minatnya lalu tulisan tersebut dipublikasikan. Publikasi itu pertama-tama dalam bentuk artikel, lalu buku, dan terakhir pidato di depan Kongres Muhammadiyah. Untuk publikasi artikel, dalam usia 19 tahun Hamka mulai mengirimkan tulisan genre jurnalistik yang dimuat koran Pelita Andalas (Medan), Seruan Islam (Pangkalan Berandan), dan majalah Suara Muhammadiyah (Yogyakarta). Yang ditulis Hamka di media massa ini berkisar pada masalah-masalah menarik yang dialaminya di Mekkah, yang untuk zaman sekarang mungkin analog dengan "laporan perjalanan." Lalu untuk publikasi buku, dalam usia 21 tahun Hamka menulis empat buku sekaligus: dua buku tentang sejarah yaitu Ringkasan Tarikh Ummat Islam dan Pembela Islam: Tarikh Sayyidina Abubakar Shiddiq yang diterbitkan oleh Pustaka Nasional, Medan; dan dua buku tentang masalah sosial keagamaan, Islam dan Adat dan Kepentingan Melakukan Tabligh yang diterbitkan oleh penerbit Anwar Rasyid, Padang Panjang. Dengan publikasi ini Hamka secara jelas mulai menunjukkan sosoknya sebagai "penulis sejarah" atau "penulis masalah sosial keagamaan." Mungkin karena publikasi ini, atau karena keaktifannya dalam pergerakan Muhammadiyah di Minangkabau, dan sudah pasti karena kepercayaan audiens Muhammadiyah terhadap kemampuan dan ketokohan Hamka muda, maka Hamkapun dianggap layak berpidato di depan kongres Muhammadiyah. Demikianlah, untuk publikasi pidato (barangkali analog dengan pidato akademik), dalam usia 22 tahun (1930) Hamka berpidato tentang "Agama Islam dalam Adat di Minangkabau" dalam Kongres Muhammadiyah ke-19 di Buktinggi, dan dalam usia 23 tahun (1931) Hamka berpidato tentang "Sejarah Islam di Sumatra" dalam Kongres Muhammadiyah ke-20 di Yogyakarta. Kedua pidato ini beberapa tahun kemudian dikembangkan dan diterbitkan jadi buku, namun yang perlu dicatat adalah bahwa pada pidato yang terakhir ini audiens amat terkesan, bahkan ada yang sampai 
menangis, yang menunjukkan keberhasilan Hamka menyajikan narasi sejarah secara persuasif kepada audiensnya.

Dari uraian di atas dapatlah disimpulkan bahwa pada umur 17-23 tahun Hamka telah mempublikasikan karya tulisnya dengan topik sejarah dalam bentuk buku, artikel, dan pidato di panggung nasional. Jika dianalogikan pada jenjang pendidikan sekarang, periode umur tersebut adalah saat-saat siswa SLTA atau bahkan mahasiswa S1 sedang "belajar menulis" atau sedang "belajar sejarah" sebagai dua kegiatan yang terpisah. Maka dalam konsep pendidikan sejarah Hamka, untuk belajar sejarah selain mengamati dan membaca siswa harus menulis.

\section{Kesimpulan}

Berdasarkan uraian dan analisa tentang sejarah kehidupan dan karya Hamka yang terkait dengan sejarah, dapat dikemukakan kesimpulan sebagai berikut:

Pertama, tujuan pengajaran sejarah menurut Hamka adalah untuk menyampaikan nilai-nilai moral dan kebenaran,. Hamka meletakkan sejarah sebagai 'ibrah, yakni kisahkisah yang mengandung nilai moral dan kebenaran; dan bukan sekedar sebagai pengungkapan fakta semata-mata. Karena itu Hamka dapat dikategorikan sabagai sejarawan dengan karakter karya sejarahnya lebih menekankan aspek pesan nilai moral yang terdapat didalamnya dari pada sejarah sebagai ilmu sebagaimana kajian sejarah yang dikemukankan para ahli lainya. Terbukti dalam penelitian ini, bahwa Hamka adalah seorang sejarawan yang melakukan pengkajian sejarah dengan sungguh-sungguh, meskipun bukan seorang akademisi khusus dalam bidang sejarah.

Kedua, meskipun tidak menulis buku tentang metode pengjaran sejarah secara khusus, berdasarkan karya-karya Hamka dalam bisang sejarah, dapat dirumuskan suatu metode pengajaran sejarah kepada anak didik. Inti utamanya adalah bahwa pesan moral dari sejarah dapat dipetik dengan menerapkan cara berpikir historis-yaitu "menunjukkan keberartian sejarah", "menggunakan sumber sejarah", "menganalisis kesinambungan dan perubahan sejarah", "mengambil sudut pandang sejarah", dan "menyajikan pesan moral sejarah." Sedangkan tahap-tahap pembelajarannya adalah dengan cara (a) membangun motivasi dan minat terhadap sejarah, (b) memupuk rasa percaya diri akan kemampuan mengkaji sejarah, (c) mendorong aktivitas membaca karya-karya sejarah (reading to learn), (d) melakukan observasi dan perbandingan (observation and comparison) dan (e) mendorong untuk belajar menulis sejarah (writing to learn).

\section{References}

[1] Abu Ja'far Muhammad ibn Jarir at-Tabari (839-923). Selain Tafsir at-Tabari. karya sejarahnya yang terkenal adalah Tarikh al-rasul wa al-muluk ed. M. A. E. Ibrahim (Kairo, 1969).

[2] Imad ad-Din Isma'il ibn 'Umar ibn Katsir (1301-1373) adalah ulama Damaskus, Syiria, yang hidup pada masa dinasti Mamluk, Bahri. Karya sejarahnya yang terkenal ialah, Al- 
bidāya wa an-nihāya fĩ at-tarīkh, ed. M. A. Makin et al (Beirut: Dār al-Kutub al-'Ilmiyya, 2005).

[3] Singkatan dari Haji Abdul Malik Karim Amrullah (1908-1981), lebih dikenal sebagai Prof. Dr. Hamka atau Hamka. Selain menulis Tafsir Al-Azhar, juga banyak menulis tentang sejarah, antara lain yang terkenal Sejarah Umat Islam (Singapura: Pustaka Nasional PTE, 2006).

[4] Azyumardi Azra, Historiografi Islam Kontemporer: Wacana, Aktualitas, dan Aktor Sejarah (Jakarta: Gramedia, 2002).

[5] Tulisannya tentang Hamka pada bagian ini berjudul "Hamka: Rihlah Kehidupan dan Kelembagaan," dalam Historiografi Islam Kontemporer, hlm. 260-297.

[6] Tim Penyusun, Sejarah Umat Islam Indonesia (Jakarta: Majlis Ulama Indonesia, 991).

[7] Kuntowijoyo, Pengantar Ilmu Sejarah (Yogyakarta: Tiara Wacana, 2003), Metodologi Sejarah (Yogyakarta: Tiara Wacana, 2003), dan Penjelasan Sejarah (Yogyakarta: Tiara Wacana, 2008).

[8] Didin Saefuddin Buchori, Metodologi Studi Islam (Bogor: Granada Sarana Pustaka, 2005) hlm. 68 .

[9] Muhammad Thohir.Sejarah Islam dari Andalusia sampai Sungai Indus. Lihat, Buchori, Ibid., hlm. 69.

[10] Azyumardi Azra, Historiografi Islam, hlm. 83.

[11] Rosihan Anwar (1922-1911) Sejarah Kecil "Petite Histoire" Indonesia, 4 jilid (Diterbitkan oleh Gramedia, Jilid I:2004, Jilid II:2009, Jilid3:2009; Jilid IV:2010). Menjelang wafat, masih sempat menulis Sutan Sjahrir: Demokrat Sejati, Pejuang Kemanusiaan 1906-1966 (Jakarta: Gramedia, 2010) dan Napak Tilas ke Belanda, 60 Tahun Perjalanan Wartawan KMB 1949 (Jakarta: Gramedia, 2010). Lihat Wikipedia, "Rosihan Anwar", http://id.wikipedia.org/wiki/ Rosihan_Anwar.

[12] Ramadhan KH (1927-2006) banyak menulis biografi tokoh-tokoh sejarah seperti A. E. Kawilarang (1988), Bang Ali (1992), Hoegeng (1993), Soemitro (1994), D.I. Panjaitan (1997), dan sebagainya. Karya biografisnya yang paling terkenal ialah tentang dua presiden Indonesia pertama: Kuantar ke Gerbang: Kisah Cinta Ibu Inggit dengan Soekarno (1981) dan Soeharto Pikiran, Tindakan, dan Ucapan Saya: Autobiografi (1988). Menjelang wafat masih sempat menulis biografi Adnan Buyung Nasution (2004). Lihat http://id.wikipedia.org/wiki/ Ramadhan_K.H.

[13] Taufik Abdullah, Islam dan Masyarakat: Pantulan Sejarah Indonesia (Jakarta: LP3ES, 1987), hlm.95. Taufik Abdullah, misalnya, mengkonfirmasi akurasi penilaian van Ronkel terhadap tokoh-tokoh Kaum Mudo dengan membandingkannya dengan gambaran yang diberikan Hamka dalam buku Ayahku. Lihat, Ibid. hlm. 223.

[14] Asvi Warman Adam, "Berpikir Historis untuk Membenahi Sejarah," pengantar untuk buku terjemahan Sam Wineburg, Berpikir Historis Memetakan Masa Depan, Mengajarkan Masa Lalu (Jakarta: Yayasan Obor, 2006). Buku ini diterjemahkan dari Sam Wineburg, Historical Thinking and Other Unnatural Acts: Charting the Future of Teaching the Past (Philadelphia: Temple University Press, 2001),

[15] Ibid, hlm.vii

[16] Ibid, hlm.vii

[17] Jakarta: Pusat Bahasa Departemen Pendidikan Nasional, 2008 hlm. 552.

[18] Selain karya Wineburg, Berpikir Historis, buku lain yang khusus membahas pendekatan berpikir historis adalah Stephane Levesque, Thinking Historically: Educating Students for the Ttwenty-first Century (Toronto: University of Toronto Press Incorporated, 2008); Keith C. Barton dan Linda S. Levstik, Teaching History for the Common Good (New Jersey: Lawrence Erlbaum Associates, Inc., 2007), dan Penney Clark (ed.), History Teaching and Learning in Canada: A State of the Art Look (Vancouver: UBC Press, 2010).

[19] Adian Husaini, “Meluruskan Sejarah Indonesia," www.insitsnet.com (diakses 6 Feb 2014). 
[20] Taufik Abdullah, "Hamka," dalam John Esposito (Ed.), Oxford Encyclopedia of The Modern Islamic World (New York: 1995), hlm. 96-97. Kutipan ini adalah terjemahan Desyanto dalam profil Pusat Kajian Hamka (Jakarta: Uhamka, 2008), hlm. 8.

[21] Diterbitkan dengan judul yang sama: M. Yunan Yusuf, Corak Pemikiran Kalam Tafsir AlAzhar (Jakarta: Pustaka Panjimas, 1990).

[22] Syamsul Nizar, Memperbincangkan Dinamika Intelektual dan Pemikiran Hamka tentang Pendidikan Islam: Seabad Hamka (Jakarta: Kencana, 2008).

[23] Diterbitkan dengan judul: Yunahar Ilyas, Kesetaraan Gender dalam Al-Quran: Studi Pemikiran Para Mufassir (Yogyakarta: Labda Press, 2006).

[24] Hamka, Antara Fakta dan Khayal "Tuanku Rao" (Jakarta: Bulan Bintang, 1971), hlm. 77.

[25] Benedeto Croce, Logic as Science of Pure Concept. Translated from Italian by Douglas Ainslie (London: MacMillan and Co, 1917), hlm. 279.

[26] Hamka, Antara Fakta dan Khayal, hlm. 77.

[27] Ibid, hlm. 100. Lihat kembali bab III tentang buku Hamka "Fakta dan Khayal Tuanku Rao."

[28] Hamka, Antara Fakta dan Khayal, hlm. 99.

[29] Ibid.

[30] Hamka, Tafsir Al-Azhar, Juz IV (Jakarta: Pustaka Panjimas, 2004), hlm. 47

[31] Hamka, Tafsir Al-Azhar, Juz I-II (Jakarta, Pustaka Panjimas, 2004), hlm. 38.

[32] Ibid, hlm. 39.

[33] Ibid, hlm.40.

[34] Ibid, hlm. 41.

[35] Tarif Khalidi, Arabic Historical Though in the Classical Period (New York: Cambridge University Press, 2002), hlm. 8.

[36] Ibid, hlm. 9.

[37] Hamka, Tafsir Al-Azhar Jilid 6 (Singapore: Pustaka Nasional PTE LTD, t.th), hlm. 41584193.

[38] Ibid, hlm. 4160.

[39] Ibid, hlm 4177.

[40] Ahmad Tafsir, "Belajar dari Sejarah," dalam bukunya Filsafat Pendidikan Islam, Cetakan Ketiga (Bandung: Remaja Rosdakarya, 2008), hlm. 143.

[41] Hamka, Kenangan-kenangan Hidup II, hlm. 95-101. Saya membiarkan penulisan ejaan sebagaimana adanya, misalnya penulisan kata depan yang tidak dipisah (seperti diatas, disini, didalam). 